\title{
Simple Recycling of Biowaste Eggshells to Various Calcium Phosphates for Specific Industries
}

\section{Nongnuch Laohavisuti}

King Mongkut's Institute of Technology Ladkrabang

Banjong Boonchom ( $\sim$ kbbanjon@gmail.com )

King Mongkut's Institute of Technology Ladkrabang

\section{Somkiat Seesanong}

King Mongkut's Institute of Technology Ladkrabang

\section{Kittichai Chaiseeda}

King Mongkut's University of Technology Thonburi

\section{Wimonmat Boonmee}

King Mongkut's Institute of Technology Ladkrabang

\section{Research Article}

Keywords: Waste eggshells, zero waste, calcium phosphates, environmentally sustainable products

Posted Date: May 4th, 2021

DOI: https://doi.org/10.21203/rs.3.rs-476484/v1

License: (9) (i) This work is licensed under a Creative Commons Attribution 4.0 International License. Read Full License

Version of Record: A version of this preprint was published at Scientific Reports on July 26th, 2021. See the published version at https://doi.org/10.1038/s41598-021-94643-1. 


\section{Abstract}

Egg consumption is very high throughout the world and with it comes enormous amount of waste eggshells. To reduce and utilize these wastes, eggshell wastes were simply transformed to low- or high-purity calcium carbonate grades by washing, crushing, and drying to use as raw materials for producing highly valuable calcium phosphate products. Low-purity calcium carbonate grade was used to prepare triple superphosphate for using in fertilizer industry, whereas high-purity calcium carbonate grade was used to produce dicalcium phosphate dihydrate, monocalcium phosphate monohydrate, and tricalcium phosphate for using in mineral feed and food additive industries. All calcium phosphate samples obtained by simple, rapid, cheap, and environmentally safe method using eggshells and phosphoric acid were identified and their structural phases and impurities were determined by XRF, XRD and FTIR techniques. The methodologies described here will be useful to manage eggshells by converting them to highly valuable products, which can solve eggshell wastes problem from industries and communities. This finding supports the viewpoint of zero waste operation to produce value-added products for obtaining sustainable development, which may be selected as an alternative way for material recycling and waste management in the future.

\section{Background}

Agro-food from fields of industries and communities produce a substantial amount of pollution every day, so it is becoming urgent to manage this problem ${ }^{1}$. As the restriction connected to environmental issues is becoming quite rigorous, it is necessary to search and develop treating systems for agro-food wastes ${ }^{1-6}$. Globally, approximately 83 million tons of eggs were produced in 2018, which of course would produce a lot of waste eggshells ${ }^{7}$. As food, eggs (chicken, duck, ostrich, turkeys, goose, and quail eggs) are used in many food menus for consumption each day and egg products in the industrialized food production (e.g., powder, liquid, and frozen forms) offer economic benefits ${ }^{1}$. In the case of agro industry, the farming of different types of animal species has a number of waste eggshells after eggs are hatched. In Thailand, egg consumption has used significant amounts of egg that account for more than 15,000 million eggs a year ${ }^{8}$. From previous research, average weight of an egg is about $60 \mathrm{~g}$, generating shell about $11 \%$; thus, the produced wastes can be estimated as being around 90,000 tons per year ${ }^{1}$. Every day thousands of eggshells are being discarded, causing serious environmental problem including unpleasant smell, noise of insects and abrasiveness of the eggshells. These wastes could be recycled and converted to valuable calcium compounds by different methods in an environmentally sound nature, which is a good choice for zero waste management.

Fundamentally, eggshells are composed of a network of protein fibers, connected with crystals of calcium carbonate $(>96 \%$ of shell weight), magnesium carbonate $(<1 \%)$, calcium phosphate $(<1 \%)$, magnesium phosphate $(<1 \%)$, silicon oxide $(<1 \%)$, and also of organic matters and water. The major composition of the shell, calcium carbonate $\left(\mathrm{CaCO}_{3}\right)$, is a crystal that occurs in the natural form of calcite phase ${ }^{1}$. Therefore, the use of these eggshells, collected greatly every day, as an alternative source of $\mathrm{CaCO}_{3}$, will help reduce the risk of microbiological and toxic problems, and may reduce the impact on the natural reserves of limestone, non-renewable natural sources. There are several extensive reviews of the applications of eggshells $s^{9-13}$. Several ways have been reported to manage eggshells waste typically destined for landfill and some others such as soil conditioner, fertilizer, animal feed, additive food, adsorbent, calcium supplement, paper manufacture, and material re-used through recycling, all having the potential to be more sustainable methods $3,14,15$. Recently, researches have studied on using eggshells for removing dyes ${ }^{16,17}$ and heavy metals ${ }^{18-24}$ from wastewater, adsorbing of phosphorus or phosphate ${ }^{25,26}$, recycling of polyvinyl chloride ${ }^{27}$, and preparing bio-adsorbent ${ }^{28}$, composites as catalyst for some reactions ${ }^{29,30}$, and nano-silver-decorated microfibrous eggshell membrane for wound healing and preventing bacterial infection ${ }^{31}$. In previous researches, eggshell wastes can be used to prepare different calcium carbonate purifications by many methods and then are used to synthesize advanced calcium salts such as calcium oxide, calcium hydroxide, various calcium phosphates, calcium citrate, calcium acetate, and calcium lactate ${ }^{1,32,33}$. Powdered eggshells have two purified calcium carbonate grades as low and high purity, which were obtained by different preparation approaches such as drying, washing, 
grinding, and calcining ${ }^{1}$. Low-purity calcium carbonate was used as animal feed, fertilizers, and heavy metal removal as described by Ok et al. ${ }^{34}$, whereas high-purity calcium carbonate was used in cosmetic and medical industry, as a base material for bio-ceramics, bone and dental implants, and anti-tartar toothpastes reported by many researchers ${ }^{1,14,35-43}$. Many researches have converted eggshells to calcium oxide $(\mathrm{CaO})$ for use as catalyst in biodiesel productions ${ }^{15,44-52}$. Other uses of eggshells are as calcium source to synthesize different calcium salts such as calcium citrate, lactate, gluconate and phosphate $^{1}$, which are used in food additive and medicine ${ }^{14}$. For calcium phosphates obtained from eggshells, many researches have studied on synthesis of different tricalcium phosphate forms $\left(\mathrm{a}, \beta\right.$, or $\left.\mathrm{\gamma}-\mathrm{Ca}{ }_{3}\left(\mathrm{PO}_{4}\right)_{2}\right)$ and hydroxyapatite $\left(\mathrm{Ca}_{10}\left(\mathrm{PO}_{4}\right)_{6}(\mathrm{OH})_{2}\right)$ to use as a base material for bio-ceramics, bone and dental implants ${ }^{32,33,37,40}$. However, calcium phosphates produced by the commonly used synthesis routes such as precipitation, sol-gel, microwave or hydrothermal route have several drawbacks, including having the obtained materials in the form of powders. Furthermore, eggshells have still not grained sufficient attention with regard to converting them from waste to new calcium phosphate materials to be used at large scale. Therefore, there are still large amount of eggshell wastes each day.

The main interest of proposing new routes is to produce four calcium phosphates (triple superphosphate $\left(\mathrm{Ca}\left(\mathrm{H}_{2} \mathrm{PO}\right)_{2} \cdot \mathrm{H}_{2} \mathrm{O}\right)$, dicalcium phosphate dihydrate $\left(\mathrm{CaHPO}_{4} \cdot 2 \mathrm{H}_{2} \mathrm{O}\right)$, monocalclium phosphate monohydrate $\left(\left(\mathrm{Ca}_{2}\left(\mathrm{H}_{2} \mathrm{PO}_{4}\right)_{2} \cdot \mathrm{H}_{2} \mathrm{O}\right)\right.$, and tricalcium phosphate $\left(\mathrm{Ca}_{3}\left(\mathrm{PO}_{4}\right)_{2}\right)$, used in fertilizer, animal feed, and food additive with enormous use in Thailand, by simple, rapid, cheap, and environmentally benign methods. The main objective of the work is to propose a new and highly competent method in terms of environmental friendliness, cost, quality, and zero-waste management. These synthesis processes offer fast reaction, easy reproducibility, high yield and without controlling various conditions to get four calcium phosphate products, which are identified by X-ray fluorescence (XRF), X-ray diffraction (XRD), and Fourier-transform infrared spectroscopy (FTIR).

\section{Results And Discussion}

Production results. Percentage yields of productions were found to be $98,97,98$ and 96 for triple superphosphate, dicalcium phosphate dihydrate, monocalcium phosphate monohydrate, and tri calcium phosphate, respectively. Chemical contents and purity of starting agents and all as-prepared products are checked by XRF method and tabulated in Table 1. These results confirm chemical formula to be $\mathrm{CaCO}_{3}$ (Ca:O ratio of 1.10:3.31 for LPC and 1.09:3.38 for HPC), $\mathrm{CaHPO}_{4} \cdot 2 \mathrm{H}_{2} \mathrm{O}$ (Ca:P ratio of 1.00:1.02), $\mathrm{Ca}\left(\mathrm{H}_{2} \mathrm{PO}_{4}\right)_{2} \cdot \mathrm{H}_{2} \mathrm{O}$ (Ca:P ratio of 1.00:2.02 for triple superphosphate and 1.00:2.05 for monocalcium phosphate dihydrate) and $\mathrm{Ca}_{3}\left(\mathrm{PO}_{4}\right)_{2}$ (Ca:P ratio of 1.47:1.00), which well agree with theoretical information. These obtained data are important for their applications such as fertilizer, feed and food because the standard of materials is indicated. 
Table 1

Compositions $( \pm 0.02 \%)$ of starting agents $\left(\mathrm{CaCO}_{3}\right.$ obtained from eggshells) and as determined by X-ray fluorescence (XRF).

Percentage values less than $0.02 \%$ (limit of detection) were omitted for clarity.

\begin{tabular}{|c|c|c|c|c|c|c|c|c|c|c|c|}
\hline \multirow[t]{2}{*}{ Samples } & \multicolumn{9}{|c|}{ Percentage of metal content (\%) } & \multicolumn{2}{|l|}{ Product purity } \\
\hline & $\mathrm{CaO}$ & $\mathrm{P}_{2} \mathrm{O}_{5}$ & LOI & $\mathrm{MgO}$ & $\mathrm{SiO}_{2}$ & $\mathrm{~K}_{2} \mathrm{O}$ & $\mathrm{CuO}$ & $\mathrm{SO}_{3}$ & $\mathrm{Fe}_{2} \mathrm{O}_{3}$ & Formula & $\%$ \\
\hline $\begin{array}{l}\text { Low-purity } \\
\text { calcium } \\
\text { carbonate } \\
\text { (LPC) }\end{array}$ & 53.25 & 0.74 & 41.48 & 1.65 & 0.56 & 0.41 & 0.28 & 0.93 & 0.71 & $\mathrm{CaCO}_{3}$ & 95.09 \\
\hline $\begin{array}{l}\text { High-purity } \\
\text { calcium } \\
\text { carbonate } \\
\text { (HPC) }\end{array}$ & 55.28 & - & 40.82 & 1.47 & 0.28 & 0.36 & 0.21 & 1.13 & 0.46 & $\mathrm{CaCO}_{3}$ & 98.71 \\
\hline $\begin{array}{l}\text { Triple } \\
\text { superphosphate } \\
\text { (fertilizer grade) }\end{array}$ & 21.32 & 54.62 & 18.18 & 2.08 & 0.92 & 0.77 & 0.31 & 0.88 & 0.91 & $\mathrm{Ca}\left(\mathrm{H}_{2} \mathrm{PO}_{4}\right)_{2} \cdot \mathrm{H}_{2} \mathrm{O}$ & 96.66 \\
\hline $\begin{array}{l}\text { Dicalcium } \\
\text { phosphate } \\
\text { dehydrate (feed } \\
\text { animal and } \\
\text { food grade) }\end{array}$ & 33.04 & 42.83 & 20.91 & 0.32 & 1.37 & 0.8 & 0.15 & 0.28 & 0.31 & $\mathrm{CaHPO}_{4} \cdot 2 \mathrm{H}_{2} \mathrm{O}$ & 99.54 \\
\hline $\begin{array}{l}\text { Monocalcium } \\
\text { phosphate } \\
\text { monohydrate } \\
\text { (feed animal } \\
\text { and food grade) }\end{array}$ & 22.4 & 55.88 & 18.7 & 0.52 & 0.58 & 1.3 & 0.11 & 0.28 & 0.23 & $\mathrm{Ca}\left(\mathrm{H}_{2} \mathrm{PO}_{4}\right)_{2} \cdot \mathrm{H}_{2} \mathrm{O}$ & 99.63 \\
\hline $\begin{array}{l}\text { Tricalcium } \\
\text { phosphate } \\
\text { (feed animal } \\
\text { and food grade) }\end{array}$ & 53.21 & 45.05 & $<0.1$ & 0.62 & 0.11 & 0.29 & 0.09 & 0.38 & 0.2 & $\mathrm{Ca}_{3}\left(\mathrm{PO}_{4}\right)_{2}$ & 98.26 \\
\hline
\end{tabular}

Characterization results. The XRD patterns from powder samples of the starting agents and the as-prepared products are shown in Figs. 2 and 3, respectively. Based on XRD spectra, the starting agents (LPC and HPC) contained calcite (CaCO, PDF no. 88-1808) ${ }^{3}$. However, the peak intensities of calcite in LPC sample decreased lower than those of HPC sample because of the effected impurity. The XRD pattern of as- prepared dicalcium phosphate dihydrate $\left(\mathrm{CaHPO}_{4} \cdot 2 \mathrm{H}_{2} \mathrm{O}\right)(\mathrm{Fig}$. $3 \mathrm{a})$ belongs to brushite $\left(\mathrm{CaHPO}_{4} \cdot 2 \mathrm{H}_{2} \mathrm{O}\right.$, PDF no. 72-0713) ${ }^{35}$. The XRD patterns of as-prepared triple superphosphate (Fig. $\left.3 \mathrm{~b}\right)$ and monocalcium phosphate monohydrate (Fig. 3c) are very similar but lower and higher peak intensities are observed because the products were obtained from different purities of calcium carbonate grades ${ }^{33}$. The lower peak intensities were observed in the XRD pattern of as-prepared triple superphosphate due to the LPC was used to the starting agent. For as-prepared tricalcium phosphate, diffraction lines attribute mainly to beta-tricalcium phosphate $\left(\mathrm{Ca}_{3}\left(\mathrm{PO}_{4}\right)_{2} \text {, PDF no. } 702065\right)^{36}$. Based on the XRD observation, it can be concluded that no impurity appeared in as-prepared HPC, dicalcium phosphate dihydrate, monocalcium phosphate monohydrate, and tricalcium phosphate powders, and some impurities appeared in as-prepared LPC and triple superphosphate samples.

Figures 4 and 5 show FTIR spectra of the starting agents (LPC and HPC) and the as-prepared products (triple superphosphate, dicalcium phosphate dihydrate, monocalcium phosphate monohydrate, and tricalcium phosphate). The FTIR spectra of as-prepared LPC (Fig. 4a) and HPC (Fig. 4b) are very similar and assigned according to vibrational modes of $\mathrm{CO}_{3}{ }^{2-}$ and $\mathrm{Ca}-\mathrm{O}$, which are block units of calcium carbonate $\left(\mathrm{CaCO}_{3}\right)$. The appeared prominent absorption peak of $\mathrm{CO}_{3}{ }^{2-}$ at $1478 \mathrm{~cm}^{-1}$ corresponds to the asymmetric stretching mode of $\mathrm{C}-\mathrm{O}$ bond. The appeared vibrational peaks at 1067, 853, and $710 \mathrm{~cm}^{-1}$ are assigned to the symmetric stretching mode of $\mathrm{C}-\mathrm{O}$ bond, out of plane and in plane bending of $\mathrm{CO}_{3}{ }^{2-}$ anion, 
respectively ${ }^{3}$. The FTIR spectra of triple superphosphate (Fig. 5a) and monocalcium phosphate monohydrate (Fig. 5b) are very similar and assigned based on the fundamental vibration of $\mathrm{Ca}\left(\mathrm{H}_{2} \mathrm{PO}_{4}\right)_{2} \cdot \mathrm{H}_{2} \mathrm{O}$. For triple superphosphate (Fig. 5a), the strong bands in the region of $1150-950$ and $450-600 \mathrm{~cm}^{-1}$ are attributed to the $\mathrm{P}-0$ stretching vibrations and the bending OPO vibrations, respectively. The couple bands at 1221 and $865 \mathrm{~cm}^{-1}$ are assigned to the in-plane P-O-H bending $\left(A_{2}\right)$, and the out of plane bending $\left(A_{1}\right)$ vibration, respectively. A weak band occurred at approximately $669 \mathrm{~cm}^{-1}$ is assigned to rocking mode involving water molecules. In the $\mathrm{O}-\mathrm{H}$ stretching mode region of the $\mathrm{H}_{2} \mathrm{PO}_{4}{ }^{-}$, which are characteristic for this compound, they appear as the A, B, C trio bands at about $3100-3200 \mathrm{~cm}^{-1}$ (A band), $2300-2400 \mathrm{~cm}^{-1}$ ( $\mathrm{B}$ band), and 1600$1800 \mathrm{~cm}^{-1}$ (C band). The vibrational bands of water molecule appear in three modes at $1646 \mathrm{~cm}^{-1}\left(\mathrm{v}_{2}\right), 3192 \mathrm{~cm}^{-1}\left(\mathrm{v}_{1}\right)$, and $3459 \mathrm{~cm}^{-1}\left(\mathrm{v}_{3}\right)$ and are assigned to bending, asymmetric stretching $(\mathrm{O}-\mathrm{H})$, and antisymmetric stretching $(\mathrm{O}-\mathrm{H})$ modes, respectively ${ }^{53}$. Vibrational modes of as-prepared dicalcium phosphate dihydrate (Fig. 5b) are assigned according to the units of $\mathrm{HPO}_{4}{ }^{2-}$ ion, $\mathrm{H}_{2} \mathrm{O}$, and $\mathrm{CaO}$. The typical intense bands at about $1370 \mathrm{~cm}^{-1}$ is due to the in-plane $\mathrm{P}-\mathrm{O}-\mathrm{H}$ bending, while the out of plane bending vibration is observed at about $893 \mathrm{~cm}^{-1}$. The strong bands at about 1120,1,060, and $984 \mathrm{~cm}^{-1} \mathrm{are}^{-}$ assigned to $\mathrm{PO}_{3}$ asymmetric stretching modes. The weak and broader band at about $569 \mathrm{~cm}^{-1}$ is corresponding to $\mathrm{PO}_{4}$ and $\mathrm{P}-\mathrm{OH}$ bending modes. The band at $499 \mathrm{~cm}^{-1}$ is assigned to $\mathrm{PO}_{3}$ symmetric bending or Ca-O stretching ${ }^{54}$. The FTIR spectrum as shown in Fig. $5 \mathrm{c}$ is very similar to the FTIR spectrum as shown in Fig. 5 a because of fundamental vibrational block units $\left(\mathrm{H}_{2} \mathrm{PO}_{4}{ }^{-}, \mathrm{CaO}, \mathrm{H}_{2} \mathrm{O}\right)$ that come from the same formula $\left(\mathrm{Ca}\left(\mathrm{H}_{2} \mathrm{PO}_{4}\right)_{2} \cdot \mathrm{H}_{2} \mathrm{O}\right)$, which are resulting vibrational frequencies are closely similar ${ }^{53}$. Finally, the $\mathrm{PO}_{4}{ }^{3-}$ and $\mathrm{CaO}$ subunits of $\mathrm{Ca}_{3}\left(\mathrm{PO}_{4}\right)_{2}$ structure are assigned (Fig. $5 \mathrm{~d}$ ). Vibrational bands of $\mathrm{PO}_{4}{ }^{3-}$ anion of the product are observed in the regions of 450-610 and $900-1000 \mathrm{~cm}^{-1}$. These bands are assigned to the $\mathrm{v}_{4}\left(\mathrm{PO}_{4}{ }^{3-}\right)$ and $\mathrm{v}_{3}\left(\mathrm{PO}_{4}{ }^{3-}\right)$ vibrations, respectively. Additionally, the observation of a strong $\mathrm{v}_{\mathrm{s}}(\mathrm{POP})$ bands $\left(725 \mathrm{~cm}^{-1}\right)$ is known to be the most striking feature of polyphosphate spectrum. The FTIR results are consistent with X-ray diffraction data.

The novelty of this work is the production methods that are simple, rapid, cost-saving and environmentally benign for the obtained calcium carbonate (raw material) and four calcium phosphate compounds, shown in Fig. 1. The eggshell wastes were accumulated about 60 tons/month from only one bakery shop in Chachoengsao Province, Thailand. Transportation of these wastes ( 60 tons) in the distance of $500-800 \mathrm{~km}$ is about 40,000 baht, which indicates the logistic cost of eggshell no more than $0.67 \mathrm{baht} / \mathrm{kg}$. The eggshells were prepared by two ways to get particle size of 50 mesh. In the first method, they were crushed only to become low-purity calcium carbonate grade, which was in the cost about $0.10 \mathrm{baht} / \mathrm{kg}$. In the second method, they were washed with detergent and crushed to become high calcium carbonate grade, which had the cost of about $0.15 \mathrm{baht} / \mathrm{kg}$. The ways of the prepared eggshells turn into low- or high-purity calcium carbonates in this work are similar with previous reports ${ }^{1,3}$. Calcium carbonate $\left(\mathrm{CaCO}_{3}\right)$ has three crystal forms as calcite, aragonite, and vaterite and is occurred from two sources: living and non-living sources. Non-living source is found in limestone mineral such as calcite $\left(\mathrm{CaCO}_{3}\right)$ and dolomite $\left(\mathrm{Ca}_{\mathrm{x}} \mathrm{Mg}_{\mathrm{y}} \mathrm{CO}_{3}, \mathrm{x}+\mathrm{y}=1\right)$, which may have impurities of other heavy metals such as lead (Pb), cadmium (Cd), arsenic (As), etc. and has limited quantity, which may run out in the future. The living source is found as the main component of pearls and the shells of marine organisms, snails, and eggs. It happens every day and is collected as large volume of wastes and without heavy toxic metal according to theory of natural selection. The low- or high-purity calcium carbonates prepared from eggshells reported in this work were investigated by XRF, XRD and FTIR techniques for confirmation of nontoxic impurities, phases, and structures. Two calcium carbonate grades obtained in this work were used as calcium sources to react with specific phosphoric acid concentration at very short time ( $<30 \mathrm{~min})$ and spontaneously dry solid products were obtained as superphosphate for phosphorus fertilizer $\left(56 \% \mathrm{P}_{2} \mathrm{O}_{5}\right)$, monocalcium phosphate, dicalcium phosphate, and tricalcium phosphate for feed animal and food additive. Carbon dioxide gas evoked in production of some calcium phosphates was tapped by quicklime to turn into calcium carbonate, which is similar method with previous reports ${ }^{55,56}$. The production methods of four calcium phosphates reported in this work were simple, rapid, cheap, and safe methods when compared with methods reported in literatures $2,4,25,33,35$ and the resulting costs were 16, 11, 18 and 24 baht/ $\mathrm{kg}$ for triple superphosphate, dicalcium phosphate dihydrate, monocalcium phosphate monohydrate, and tricalcium phosphate, respectively. The characterizations of four calcium phosphates were performed using XRF, XRD and FTIR techniques. 
Impurities, phases and structures were used to confirm that the obtained products were "Green Products" (no metal toxic impurities and according to standard material product) to replace the same products in Thailand markets. All obtained based on this work lead to transforming or recycling of eggshells to four calcium phosphates with lower or near prices and "green products" compared with the same products in the markets. Therefore, eggshell wastes from anywhere can be used to prepare calcium phosphates by methods reported in this work, which will be alternatives to remove these wastes from environmental problem in the future. The authors suggest that pilot projects are required to evaluate their implementation to a commercial scale by using these cleaner production processes to convert waste into industrially viable resources in the future.

\section{Materials And Methods}

Preparation of raw materials. Eggshell wastes were obtained from commercial food, bakery, and cake shop (Chachoengsao Province, Thailand), which were normally stored 2 tons a day. These wastes were turned into 2 levels of calcium carbonate purity, low- and high-purity grades, as raw materials for producing fertilizer and feed mineral, respectively. Figure 1 shows a general flowchart of the preparation process of the two calcium carbonate grades from egg shells.

Low-purity calcium carbonate (LPC) was prepared by crushing egg shells followed by sieving through a 50 mesh with grinder machine. Thus, coarse powders with purity levels of $94-97 \%$ in calcium carbonate that would be used to produce phosphate fertilizers were obtained.

High-purity calcium carbonate (HPC) was prepared by treating egg shells as follow: washed with household detergent, crushed and sieved through a 50 mesh with grinder machine and then calcined at $500^{\circ} \mathrm{C}$ for $2 \mathrm{~h}$ with a furnace. Subsequently, coarse powders with purity levels of $97-99 \%$ in calcium carbonate that will be used to produce animal feed and food additive are obtained.

Commercial-grade phosphoric acid $\left(85 \% \mathrm{w} / \mathrm{w} \mathrm{H}_{3} \mathrm{PO}_{4}\right)$ was used without prior purification. Two concentrations of phosphoric acid prepared by dilution with water are 50 and $70 \% \mathrm{w} / \mathrm{w} \mathrm{H}_{3} \mathrm{PO}_{4}$. In a typical process, $10 \mathrm{~kg}$ of $85 \% \mathrm{w} / \mathrm{w} \mathrm{H}_{3} \mathrm{PO}_{4}$ were added to 7 and $2.15 \mathrm{~kg}$ of water for preparing 50 and $70 \% \mathrm{H}_{3} \mathrm{PO}_{4}$, respectively. The dilution reactions were strong exothermic processes which occurred at temperature range of $50-70^{\circ} \mathrm{C}$.

Production of calcium phosphate compounds. Triple superphosphate $\left(\mathrm{Ca}\left(\mathrm{H}_{2} \mathrm{PO}_{4}\right)_{2} \cdot \mathrm{H}_{2} \mathrm{O}\right)$, fertilizer containing more than $56 \%$ of available phosphoric acid $\left(\mathrm{P}_{2} \mathrm{O}_{5}\right)$ was prepared as follow. At beginning procedure, $3 \mathrm{~kg}$ of $\mathrm{LPC}$ was placed in a plastic container $(20 \mathrm{~L})$. Then $5 \mathrm{~L}$ of $70 \% \mathrm{w} / \mathrm{w} \mathrm{H}_{3} \mathrm{PO}_{4}$ were slowly added and followed by stirring at $100 \mathrm{rpm}$ for about $15 \mathrm{~min}$. The resulting reaction was strong exothermic and was aged in a plastic container for about 60-120 min to dry spontaneously and then was ground to fine powder. The white-yellow product $\left(\mathrm{Ca}\left(\mathrm{H}_{2} \mathrm{PO}_{4}\right)_{2} \cdot \mathrm{H}_{2} \mathrm{O}\right)(\mathrm{Fig}$. 2), triple super phosphate is obtained by a simple, rapid, and low-cost production process according to Eq. 1:

$\mathrm{CaCO}_{3}(\mathrm{~s})+2 \mathrm{H}_{3} \mathrm{PO}_{4}(70 \% \mathrm{w} / \mathrm{w}) \rightarrow \mathrm{Ca}\left(\mathrm{H}_{2} \mathrm{PO}_{4}\right)_{2} \cdot \mathrm{H}_{2} \mathrm{O}(\mathrm{s})+\mathrm{CO}_{2}(\mathrm{~g})(1)$

Dicalcium phosphate dihydrate $\left(\mathrm{CaHPO}_{4} \cdot 2 \mathrm{H}_{2} \mathrm{O}\right)$, feed and food grade containing $18 \%$ of phosphorus and $24 \%$ of calcium, was produced as follows: in the starting process, $5 \mathrm{~kg}$ of HPC was placed in a plastic container ( $20 \mathrm{~L})$, followed by the immediate addition of $5 \mathrm{~L}$ of $50 \% \mathrm{w} / \mathrm{w} \mathrm{H}_{3} \mathrm{PO}_{4}$ and then stirring at $100 \mathrm{rpm}$ for about $20 \mathrm{~min}$. Finally, the resulting reaction which was moderately exothermic was aged in a plastic container for about 50-70 min to dry spontaneously and then was ground to fine powder and the white product of dicalcium phosphate $\left(\mathrm{CaHPO}_{4} \cdot 2 \mathrm{H}_{2} \mathrm{O}\right)$ is obtained (Fig. 2). This reaction is simple, quick, and cheap and is shown in Eq. 2.

$\mathrm{CaCO}_{3}(\mathrm{~s})+\mathrm{H}_{3} \mathrm{PO}_{4}(50 \% \mathrm{w} / \mathrm{w})+\mathrm{H}_{2} \mathrm{O}(\mathrm{l}) \rightarrow \mathrm{CaHPO}_{4} \cdot 2 \mathrm{H}_{2} \mathrm{O}(\mathrm{s})+\mathrm{CO}_{2}(\mathrm{~g})(2)$ 
Monocalcium phosphate monohydrate $\left(\mathrm{Ca}\left(\mathrm{H}_{2} \mathrm{PO}_{4}\right)_{2} \cdot \mathrm{H}_{2} \mathrm{O}\right)$, feed and food grade containing $21 \%$ of phosphorus and $15 \%$ of calcium, was prepared similarly to triple superphosphate but using HPC as starting agent and the final white powder product was obtained (Fig. 2).

Tricalcium phosphate $\left(\mathrm{Ca}_{3}\left(\mathrm{PO}_{4}\right)_{2}\right)$ (Fig. 1), food grade containing $44 \%$ of phosphorus and $38 \%$ of calcium, was synthesized as follows: in a typical route, $2.52 \mathrm{~kg}$ of monocalcium phosphate monohydrate $\left(\mathrm{Ca}\left(\mathrm{H}_{2} \mathrm{PO}_{4}\right)_{2} \cdot \mathrm{H}_{2} \mathrm{O}\right)$ and $1.0 \mathrm{~kg}$ of $\mathrm{HPC}$ were thoroughly mixed by ball milling. Then the resulting mixture was transferred into a ceramic container and then was calcined at $900^{\circ} \mathrm{C}$ for $2 \mathrm{~h}$ in a furnace. The calcined product was obtained as white powder corresponding to Eq. 3.

$2 \mathrm{CaCO}_{3}(\mathrm{~s})+\mathrm{Ca}\left(\mathrm{H}_{2} \mathrm{PO}_{4}\right)_{2} \cdot \mathrm{H}_{2} \mathrm{O}(\mathrm{s}) \rightarrow \mathrm{Ca}_{3}\left(\mathrm{PO}_{4}\right)_{2}(\mathrm{~s})+2 \mathrm{CO}_{2}(\mathrm{~g})+3 \mathrm{H}_{2} \mathrm{O}(\mathrm{g})$ at $900^{\circ} \mathrm{C}(3)$

Characterization. The starting materials and as-prepared products were obtained and identified. Four analyses were carried out in this study: X-ray Fluorescence (XRF, Bruker S4 Pioneer), X-Ray Diffraction (XRD, Bruker D8 Advance), Fourier-Transform Infrared Spectrophotometer (FTIR, Perkin Elmer Spectrum GX) and Thermogravimetric Analyzer (TGA, Perkin Elmer Pyris I). The crystal structures of samples were estimated using XRD in $2 \theta$ range of $1-60^{\circ}$ with a step size of 0.05 and a step time of $1 \mathrm{~s}$. The room temperature FTIR spectra were recorded in the range of $4,000-400 \mathrm{~cm}^{-1}$ with eight scans on a Perkin-Elmer Spectrum GX spectrometer with the resolution of $4 \mathrm{~cm}^{-1}$. Thermal analysis was used to characterize water content in the asprepared samples as dicalcium phosphate dihydrate, triple superphosphate, and monocalcium phosphate monohydrate.

\section{Conclusions}

Waste eggshells represented one of the most urging problems of agricultural and food industries as well as communities, due to their enormous amount that must be disposed of in some way nowadays. This research described an alternative way to recycle wastes as added-value products to solve eggshell problem of industries and communities. The as-prepared raw materials (low- and high-purity calcium carbonate (LPC and HPC) and products (triple superphosphate, dicalcium phosphate dihydrate, monocalcium phosphate monohydrate, and tricalcium phosphate) were produced by simple, rapid, cheap, and environmentally benign method. Identification of structural phase and impurity of all as-prepared samples was confirmed by XRF, TGA, XRD and FTIR techniques. The findings indicate that all as-prepared samples can be used in industries of fertilizer, animal feed and food additive, which require massive amounts. Therefore, the study represents alternative ways of the environmental benefits resulting from possible transformation of eggshells to value-added calcium compounds needed for wide uses in many industries. If the eggshells are recycled as described above, then a future of these wastes will be used to produce value-added products, which take care of the environment according to the way of zero waste and corresponding to sustainable development.

\section{Declarations}

\section{Acknowledgments}

This work was supported by the Thailand Science Research and Innovation (TSRI)

(RE-KRIS/008/64).

\section{Author contributions}

N.L. carried out the experiments and analysis. B.B. designed the study, contributed in the experiments and analysis and wrote the main manuscript text. S.S. and W.B. contributed in characterization and analysis. K.C. contributed in the experiments and analysis and proved the main manuscript text. All the authors analyzed the results, contributed in discussion and to writing the manuscript.

\section{Competing interests}


The authors declare no competing interests.

\section{References}

1 Oliveira, D. A., Benelli, P. \& Amante, E. R. A literature review on adding value to solid residues: egg shells. J. Clean. Prod.46, 42-47, https://doi.org/10.1016/j.jclepro.2012.09.045 (2013).

2 Christmas, R. B. \& Harms, R. H. Utilization of egg shells and phosphoric acid as a source of phosphorus and calcium in the diet of white leghorn cockerels. Poult. Sci.55, 264-267, https://doi.org/10.3382/ps.0550264 (1976).

3 Barros, M. C., Bello, P. M., Bao, M. \& Torrado, J. J. From waste to commodity: transforming shells into high purity calcium carbonate. J. Clean. Prod.17, 400-407, https://doi.org/10.1016/j.jclepro.2008.08.013 (2009).

4 Cho, M. G., Bae, S. M. \& Jeong, J. Y. Egg shell and oyster shell powder as alternatives for synthetic phosphate: effects on the quality of cooked ground pork products. Korean J. Food Sci. Anim. Resour.37, 571-578, https://doi.org/10.5851/kosfa.2017.37.4.571 (2017).

5 Ummartyotin, S. \& Manuspiya, H. A critical review of eggshell waste: an effective source of hydroxyapatite as photocatalyst. J. Met. Mater. Miner.28, 124-135, https://doi.org/10.14456/jmmm.2018.17 (2018).

6 Arvanitoyannis, I. S. Waste Management for the Food Industries. (Academic Press, 2008).

7 FAOSTAT statistical database (Food and Agriculture Organization of the United Nations, 2020).

8 Mookprom, S., Boonkum, W., Kunhareang, S., Siripanya, S. \& Duangjinda, M. Genetic evaluation of egg production curve in Thai native chickens by random regression and spline models. Poult. Sci.96, 274-281, https://doi.org/10.3382/ps/pew326 (2017).

9 Waheed, M. et al. Channelling eggshell waste to valuable and utilizable products: A comprehensive review. Trends Food Sci. Technol.106, 78-90, https://doi.org/10.1016/j.tifs.2020.10.009 (2020).

10 Waheed, M. et al. Eggshell calcium: A cheap alternative to expensive supplements. Trends Food Sci. Technol.91, 219-230, https://doi.org/10.1016/j.tifs.2019.07.021 (2019).

11 Balaz, M. Ball milling of eggshell waste as a green and sustainable approach: A review. Adv. Colloid Interface Sci.256, 256275, https://doi.org/10.1016/j.cis.2018.04.001 (2018).

12 Guo, Y. et al. Enhanced catalytic benzene oxidation over a novel waste-derived Ag/eggshell catalyst. J. Mater. Chem. A7, 8832-8844, https://doi.org/10.1039/c8ta10822f (2019).

13 Guru, P. S. \& Dash, S. Sorption on eggshell waste-A review on ultrastructure, biomineralization and other applications. Adv. Colloid Interface Sci.209, 49-67, https://doi.org/10.1016/j.cis.2013.12.013 (2014).

14 Yoo, S., Hsieh, J. S., Zou, P. \& Kokoszka, J. Utilization of calcium carbonate particles from eggshell waste as coating pigments for ink-jet printing paper. Bioresour. Technol.100, 6416-6421, https://doi.org/10.1016/j.biortech.2009.06.112 (2009).

15 Laca, A., Laca, A. \& Díaz, M. Eggshell waste as catalyst: A review. J. Environ. Manage.197, 351-359, https://doi.org/10.1016/j.jenvman.2017.03.088 (2017).

16 Tsai, W.-T. et al. Utilization of ground eggshell waste as an adsorbent for the removal of dyes from aqueous solution. Bioresour. Technol.99, 1623-1629, https://doi.org/10.1016/j.biortech.2007.04.010 (2008). 
17 Rápó, E. et al. Adsorption of remazol brilliant violet-5R textile dye from aqueous solutions by using eggshell waste biosorbent. Sci. Rep.10, 8385, https://doi.org/10.1038/s41598-020-65334-0 (2020).

18 Ahmad, M. et al. Eggshell and coral wastes as low cost sorbents for the removal of $\mathrm{Pb}^{2+}, \mathrm{Cd}^{2+}$ and $\mathrm{Cu}^{2+}$ from aqueous solutions. J. Ind. Eng. Chem.18, 198-204, https://doi.org/10.1016/j.jiec.2011.11.013 (2012).

19 Park, H. J., Jeong, S. W., Yang, J. K., Kim, B. G. \& Lee, S. M. Removal of heavy metals using waste eggshell. J. Environ. Sci.19, 1436-1441, https://doi.org/10.1016/s1001-0742(07)60234-4 (2007).

20 Zheng, W. et al. Adsorption of Cd(II) and Cu(II) from aqueous solution by carbonate hydroxylapatite derived from eggshell waste. J. Hazard. Mater.147, 534-539, https://doi.org/10.1016/j.jhazmat.2007.01.048 (2007).

21 Mignardi, S., Archilletti, L., Medeghini, L. \& De Vito, C. Valorization of eggshell biowaste for sustainable environmental remediation. Sci. Rep.10, 2436, https://doi.org/10.1038/s41598-020-59324-5 (2020).

22 Imam, D. M., Moussa, S. I. \& Attallah, M. F. Sorption behavior of some radionuclides using prepared adsorbent of hydroxyapatite from biomass waste material. J. Radioanal. Nucl. Chem.319, 997-1012, https://doi.org/10.1007/s10967-01806403-7 (2019).

23 Renu, M. A., Singh, K., Upadhyaya, S. \& Dohare, R. K. Removal of heavy metals from wastewater using modified agricultural adsorbents. Mater. Today Proc.4, 10534-10538, https://doi.org/10.1016/j.matpr.2017.06.415 (2017).

24 De Angelis, G., Medeghini, L., Conte, A. M. \& Mignardi, S. Recycling of eggshell waste into low-cost adsorbent for Ni removal from wastewater. J. Clean. Prod.164, 1497-1506, https://doi.org/10.1016/j.jclepro.2017.07.085 (2017).

25 Panagiotou, E. et al. Turning calcined waste egg shells and wastewater to Brushite: phosphorus adsorption from aqua media and anaerobic sludge leach water. J. Clean. Prod.178, 419-428, https://doi.org/10.1016/j.jclepro.2018.01.014 (2018).

26 Liu, X., Shen, F. \& Qi, X. Adsorption recovery of phosphate from aqueous solution by CaO-biochar composites prepared from eggshell and rice straw. Sci. Total Environ.666, 694-702, https://doi.org/10.1016/j.scitotenv.2019.02.227 (2019).

27 Balaz, M., Bujnakova, Z., Achimovicova, M., Tesinsky, M. \& Balaz, P. Simultaneous valorization of polyvinyl chloride and eggshell wastes by a semi-industrial mechanochemical approach. Environ. Res.170, 332-336,

https://doi.org/10.1016/j.envres.2018.12.005 (2019).

28 Zhang, N. et al. Enhanced bio-methane production from ammonium-rich waste using eggshell-and lignite-modified zeolite (ELMZ) as a bio-adsorbent during anaerobic digestion. Process Biochem.81, 148-155, https://doi.org/10.1016/j.procbio.2019.03.001 (2019).

29 Guo, Y. et al. Biogenic Pt/ $\mathrm{CaCO}_{3}$ nanocomposite as a robust catalyst toward benzene oxidation. ACS Appl. Mater. Interfaces12, 2469-2480, https://doi.org/10.1021/acsami.9b18490 (2020).

30 Zhang, X. et al. Waste eggshell-derived dual-functional CuO/ZnO/eggshell nanocomposites: (photo)catalytic reduction and bacterial inactivation. ACS Sustainable Chem. Eng.7, 15762-15771, https://doi.org/10.1021/acssuschemeng.9b04083 (2019).

31 Liu, M. et al. Nano-silver-decorated microfibrous eggshell membrane: processing, cytotoxicity assessment and optimization, antibacterial activity and wound healing. Sci. Rep.7, 436, https://doi.org/10.1038/s41598-017-00594-x (2017).

32 Rivera, E. M. et al. Synthesis of hydroxyapatite from eggshells. Mater. Lett.41, 128-134, https://doi.org/10.1016/s0167577x(99)00118-4 (1999). 
33 Francis, A. A. \& Abdel Rahman, M. K. The environmental sustainability of calcined calcium phosphates production from the milling of eggshell wastes and phosphoric acid. J. Clean. Prod.137, 1432-1438,

https://doi.org/10.1016/j.jclepro.2016.08.029 (2016).

34 Ok, Y. S. et al. Application of eggshell waste for the immobilization of cadmium and lead in a contaminated soil. Environ. Geochem. Health33, 31-39, https://doi.org/10.1007/s10653-010-9362-2 (2011).

35 Balázsi, C., Wéber, F., Kövér, Z., Horváth, E. \& Németh, C. Preparation of calcium-phosphate bioceramics from natural resources. J. Eur. Ceram. Soc.27, 1601-1606, https://doi.org/10.1016/j.jeurceramsoc.2006.04.016 (2007).

36 Lee, S.-J., Yoon, Y.-S., Lee, M.-H. \& Oh, N.-S. Highly sinterable $\beta$-tricalcium phosphate synthesized from eggshells. Mater. Lett.61, 1279-1282, https://doi.org/10.1016/j.matlet.2006.07.008 (2007).

37 Siva Rama Krishna, D., Siddharthan, A., Seshadri, S. K. \& Sampath Kumar, T. S. A novel route for synthesis of nanocrystalline hydroxyapatite from eggshell waste. J. Mater. Sci.: Mater. Med.18, 1735-1743, https://doi.org/10.1007/s10856-007-3069-7 (2007).

38 Liao, D. et al. Removal of lead(II) from aqueous solutions using carbonate hydroxyapatite extracted from eggshell waste. J. Hazard. Mater.177, 126-130, https://doi.org/10.1016/j.jhazmat.2009.12.005 (2010).

39 Gergely, G. et al. Preparation and characterization of hydroxyapatite from eggshell. Ceram. Int.36, 803-806, https://doi.org/10.1016/j.ceramint.2009.09.020 (2010).

40 Chaudhuri, B., Mondal, B., Modak, D. K., Pramanik, K. \& Chaudhuri, B. K. Preparation and characterization of nanocrystalline hydroxyapatite from egg shell and $\mathrm{K}_{2} \mathrm{HPO}_{4}$ solution. Mater. Lett.97, 148-150, https://doi.org/10.1016/j.matlet.2013.01.082 (2013).

41 Cho, J. S., Lee, J.-H. \& Kang, Y. C. Large scale production of yolk-shell $\beta$-tricalcium phosphate powders, and their bioactivities as novel bone substitutes. Phys. Chem. Chem. Phys.16, 16962-16967, https://doi.org/10.1039/c4cp01808g (2014).

42 Ibrahim, A.-R., Wei, W., Zhang, D., Wang, H. \& Li, J. Conversion of waste eggshells to mesoporous hydroxyapatite nanoparticles with high surface area. Mater. Lett.110, 195-197, https://doi.org/10.1016/j.matlet.2013.08.014 (2013).

$43 \mathrm{Wu}$, S.-C. et al. A hydrothermal synthesis of eggshell and fruit waste extract to produce nanosized hydroxyapatite. Ceram. Int.39, 8183-8188, https://doi.org/10.1016/j.ceramint.2013.03.094 (2013).

44 Wei, Z., Xu, C. \& Li, B. Application of waste eggshell as low-cost solid catalyst for biodiesel production. Bioresour. Technol.100, 2883-2885, https://doi.org/10.1016/j.biortech.2008.12.039 (2009).

45 Buasri, A., Chaiyut, N., Loryuenyong, V., Wongweang, C. \& Khamsrisuk, S. Application of eggshell wastes as a heterogeneous catalyst for biodiesel production. Sustain. Energy1, 7-13, https://doi.org/10.12691/rse-1-2-1 (2013).

46 Mosaddegh, E. \& Hassankhani, A. Application and characterization of eggshell as a new biodegradable and heterogeneous catalyst in green synthesis of 7,8-dihydro-4H-chromen-5(6H)-ones. Catal. Commun.33, 70-75, https://doi.org/10.1016/j.catcom.2012.12.013 (2013).

47 Rohim, R., Ahmad, R., Ibrahim, N., Hamidin, N. \& Abidin, C. Z. A. Characterization of calcium oxide catalyst from eggshell waste. Adv. Environ. Biol., 35+ (2014).

48 Yasar, F. Biodiesel production via waste eggshell as a low-cost heterogeneous catalyst: Its effects on some critical fuel properties and comparison with CaO. Fue/255, 115828, https://doi.org/10.1016/j.fuel.2019.115828 (2019). 
49 Pandit, P. R. \& Fulekar, M. H. Biodiesel production from microalgal biomass using CaO catalyst synthesized from natural waste material. Renew. Energy136, 837-845, https://doi.org/10.1016/j.renene.2019.01.047 (2019).

50 Khemthong, P. et al. Industrial eggshell wastes as the heterogeneous catalysts for microwave-assisted biodiesel production. Catal. Today190, 112-116, https://doi.org/10.1016/j.cattod.2011.12.024 (2012).

51 Kavitha, V., Geetha, V. \& Jacqueline, P. J. Production of biodiesel from dairy waste scum using eggshell waste. Process Saf. Environ. Prot.125, 279-287, https://doi.org/10.1016/j.psep.2019.03.021 (2019).

52 Borah, M. J., Das, A., Das, V., Bhuyan, N. \& Deka, D. Transesterification of waste cooking oil for biodiesel production catalyzed by Zn substituted waste egg shell derived $\mathrm{CaO}$ nanocatalyst. Fue/242, 345-354, https://doi.org/10.1016/j.fuel.2019.01.060 (2019).

53 Boonchom, B. Parallelogram-like microparticles of calcium dihydrogen phosphate monohydrate $\left(\mathrm{Ca}\left(\mathrm{H}_{2} \mathrm{PO}_{4}\right)_{2} \cdot \mathrm{H}_{2} \mathrm{O}\right)$ obtained by a rapid precipitation route in aqueous and acetone media. J. Alloys Compd.482, 199-202, https://doi.org/10.1016/j.jallcom.2009.03.157 (2009).

54 Rattanai, B., Naratip, V. \& Banjong, B. Study on thermal transformation of CuHPO ${ }_{4} \cdot \mathrm{H}_{2} \mathrm{O}$ obtained by acetone-mediated synthesis at ambient temperature. J. Therm. Anal. Calorim.110, 625-632, https://doi.org/10.1007/s10973-011-1832-y (2011).

55 Lim, M., Han, G.-C., Ahn, J.-W. \& You, K.-S. Environmental remediation and conversion of carbon dioxide $\left(\mathrm{CO}_{2}\right)$ into useful green products by accelerated carbonation technology. Int. J. Environ. Res. Public Health7, 203-228, https://doi.org/10.3390/ijerph7010203 (2010).

56 Kemperl, J. \& Maček, J. Precipitation of calcium carbonate from hydrated lime of variable reactivity, granulation and optical properties. Int. J. Miner. Process.93, 84-88, https://doi.org/10.1016/j.minpro.2009.05.006 (2009).

\section{Figures}




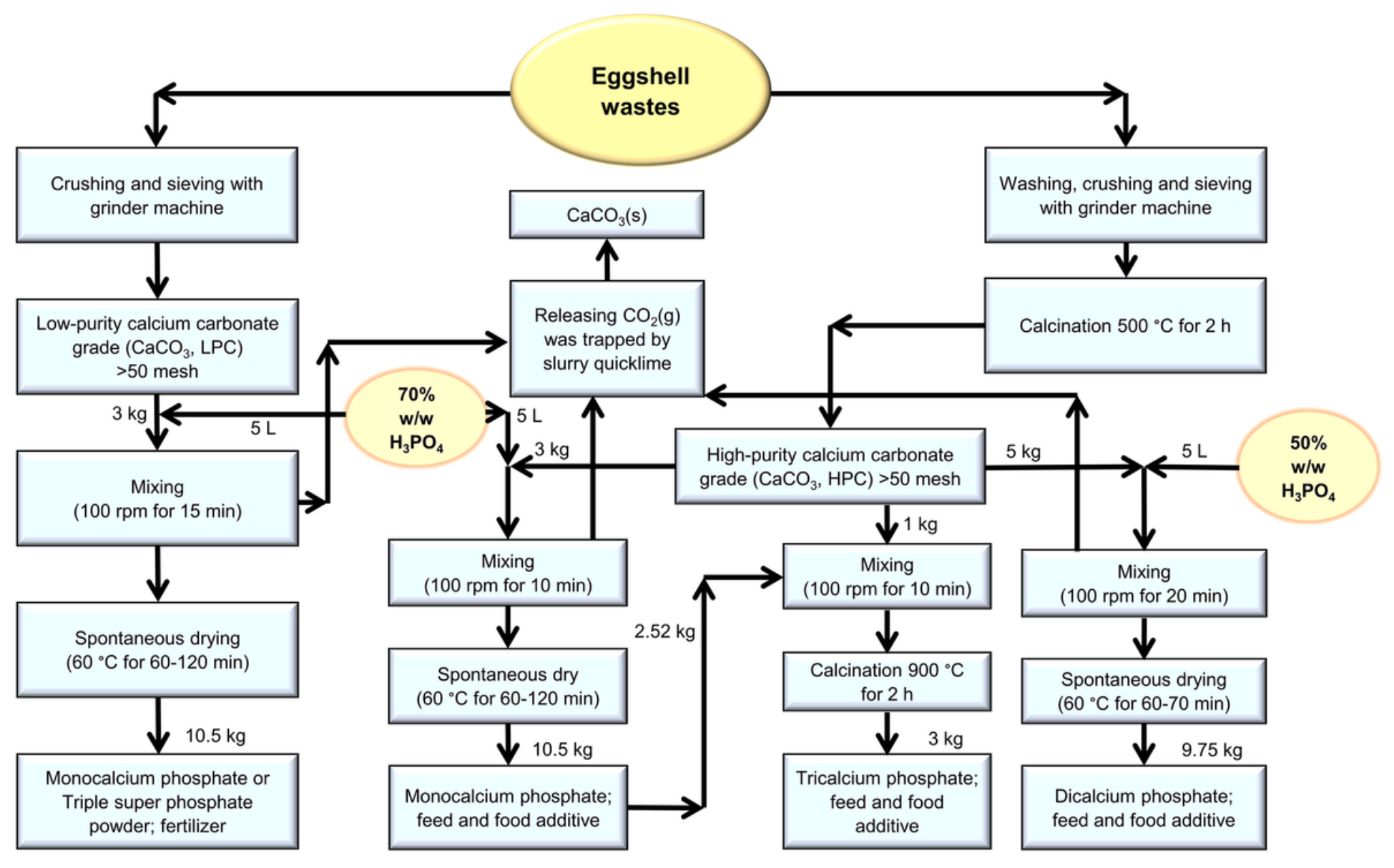

\section{Figure 1}

Process flowchart of low- and high-purity calcium carbonates obtained from eggshells and four calcium phosphate products. 


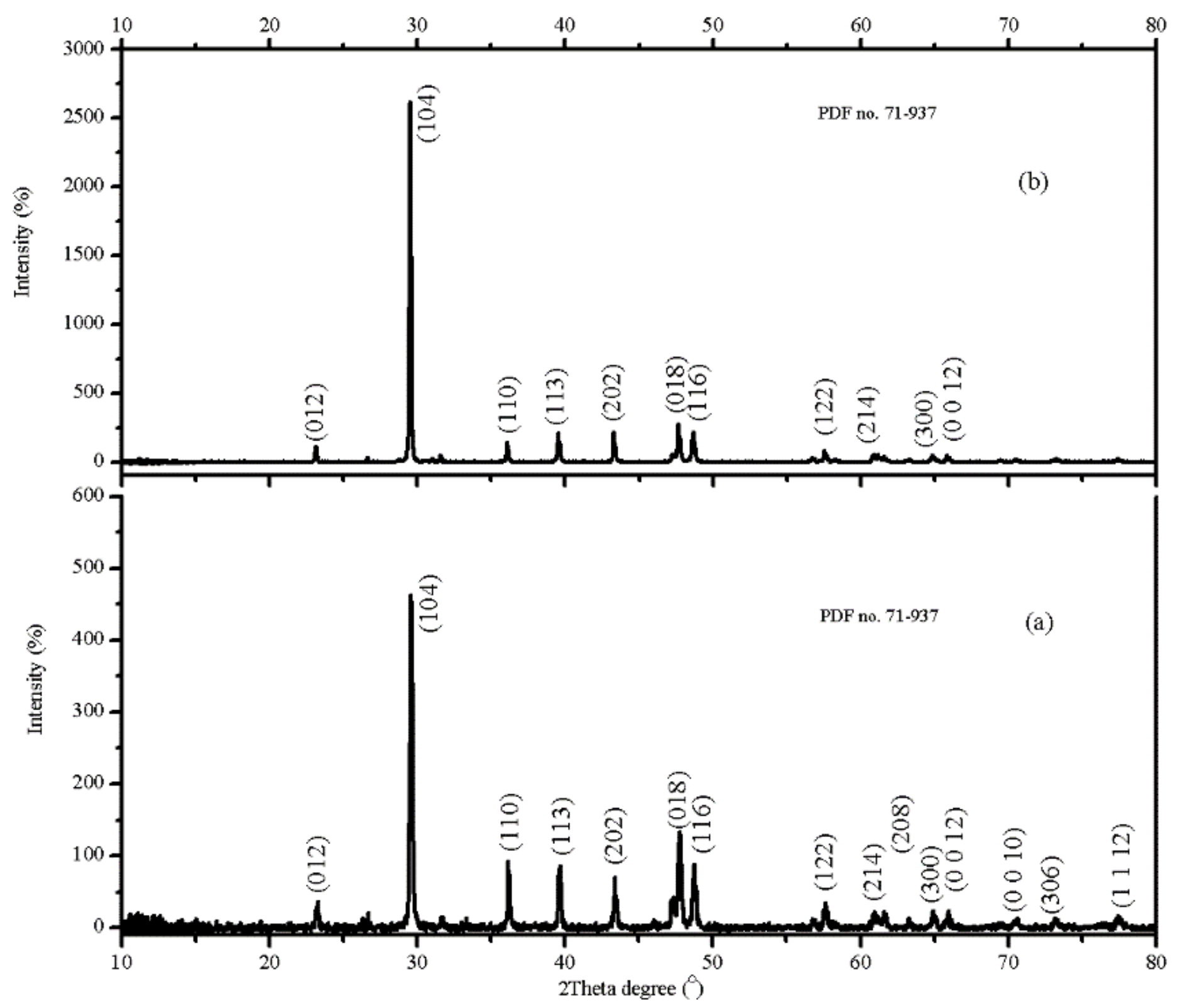

Figure 2

X-ray diffraction patterns of low-purity (a) and high-purity (b) calcium carbonates obtained from powdered eggshell samples. 


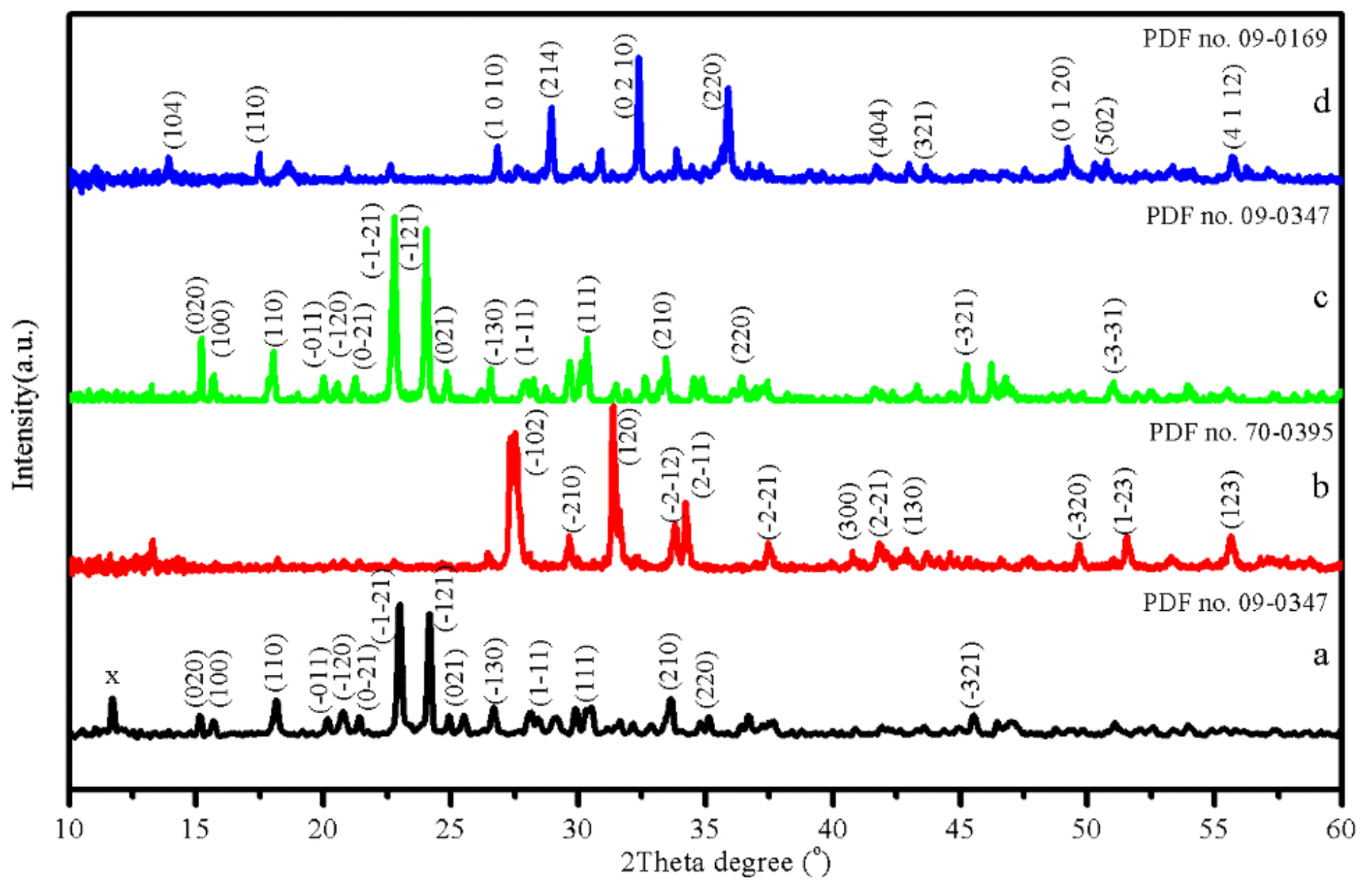

Figure 3

X-ray diffraction patterns of triple superphosphate (a), dicalcium phosphate dihydrate (b), monocalcium phosphate monohydrate (c), and tricalcium phosphate (d). 


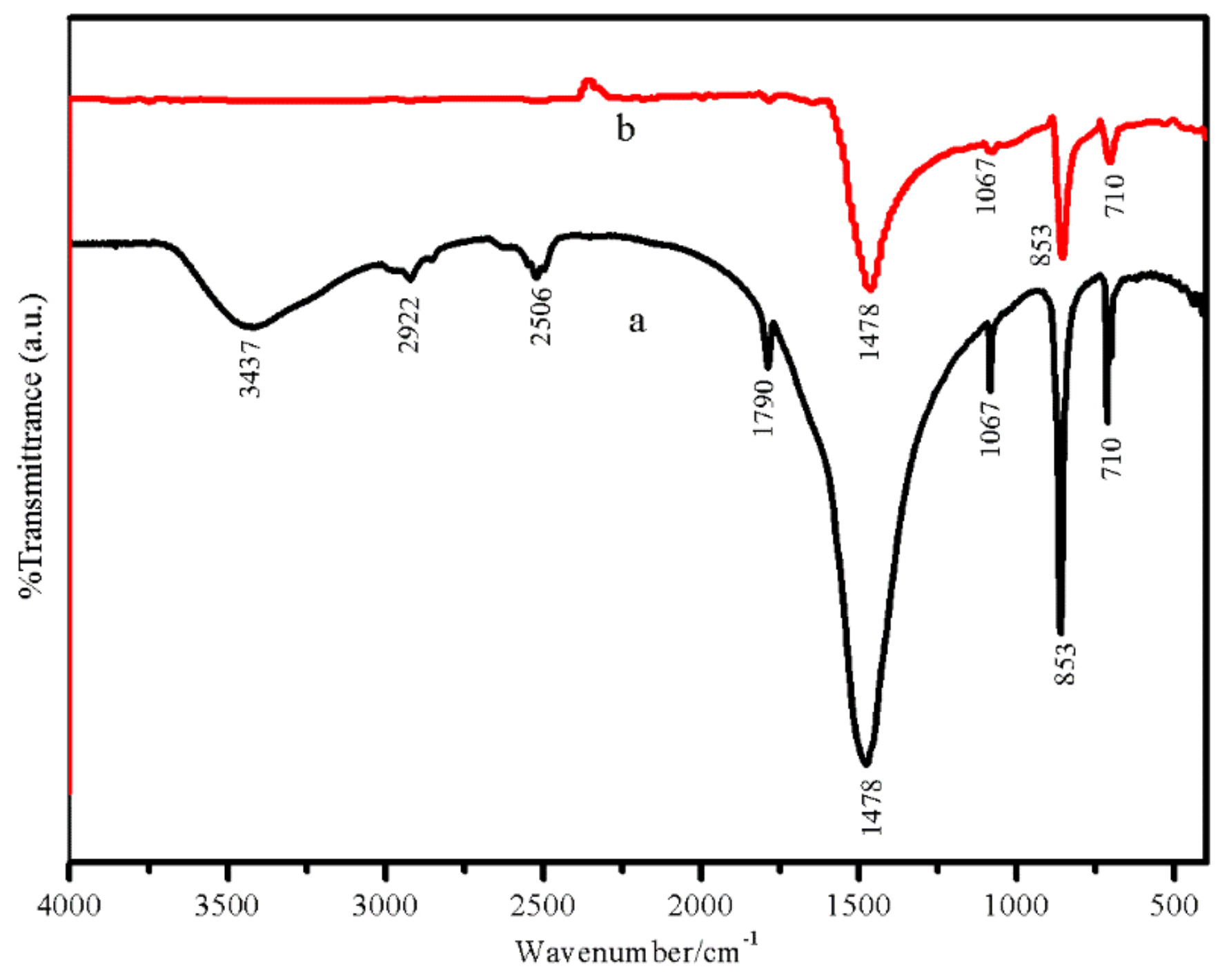

Figure 4

FTIR spectra of low-purity (a) and high-purity (b) calcium carbonates obtained from powdered eggshell samples. 


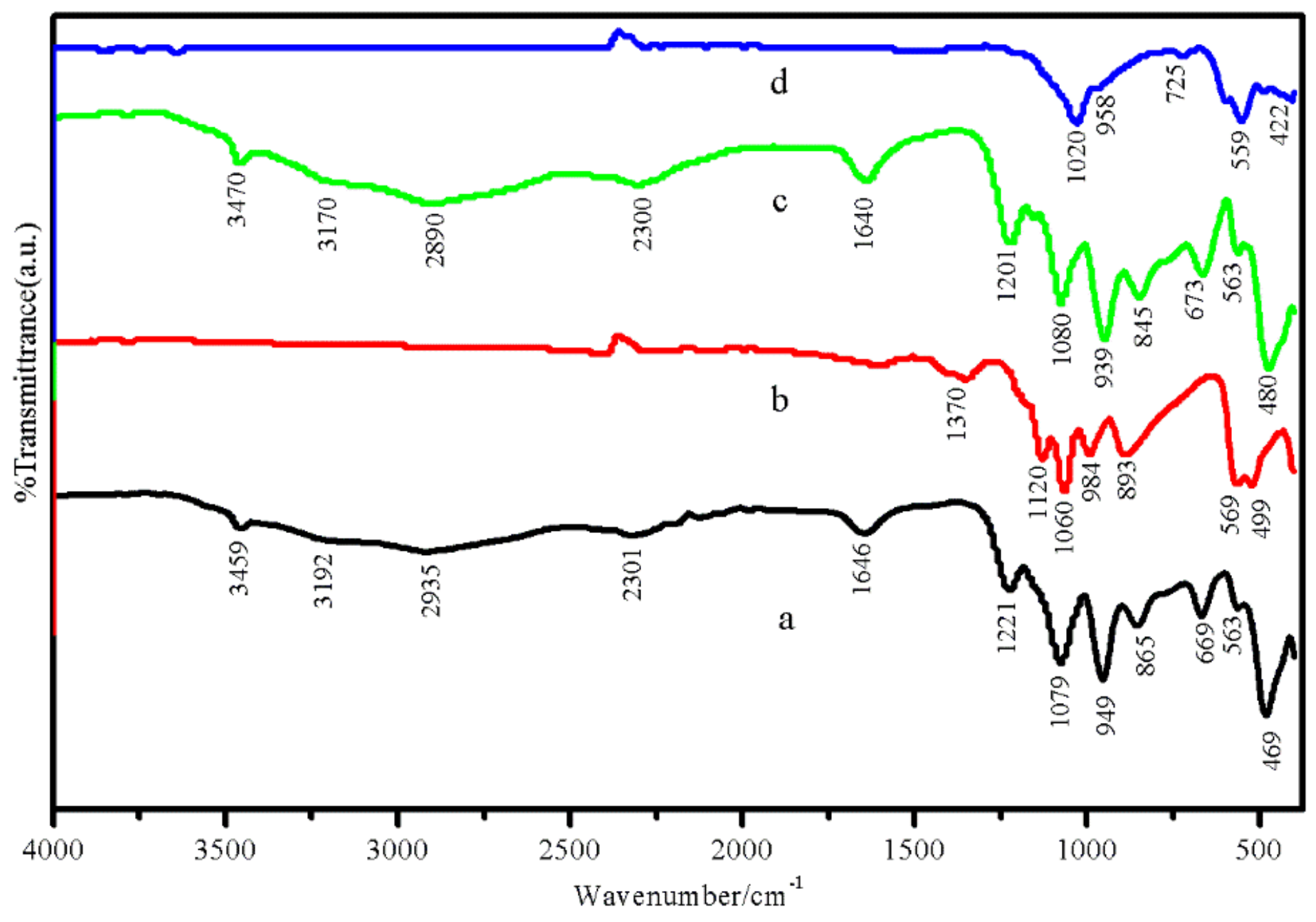

Figure 5

FTIR spectra of triple superphosphate (a), dicalcium phosphate dihydrate (b), monocalcium phosphate monohydrate (c), and tricalcium phosphate (d). 